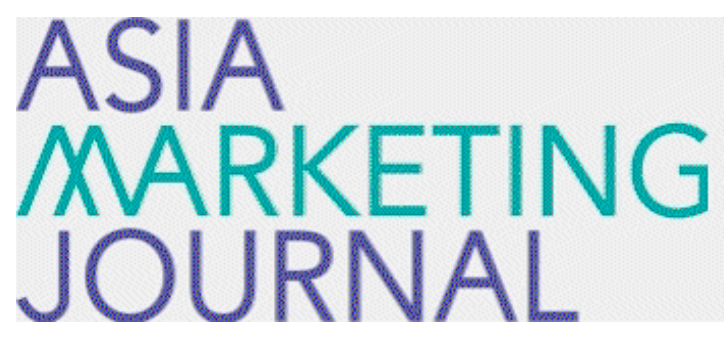

ASIA MARKETING JOURNAL

Volume 15 | Issue 4

Article 11

$1-30-2014$

\title{
Fantastic Collaboration of Financial Services and Telecommunication
}

\author{
Seon Min Lee \\ Seung Woo Chun \\ Young Hyuck Joo \\ Yoo
}

Follow this and additional works at: https://amj.kma.re.kr/journal

Part of the Marketing Commons

\section{Recommended Citation}

Lee, Seon Min; Chun, Seung Woo; Joo, Young Hyuck; and Yoo (2014) "Fantastic Collaboration of Financial Services and Telecommunication," Asia Marketing Journal: Vol. 15 : Iss. 4 , Article 11.

Available at: https://doi.org/10.53728/2765-6500.1574

This Article is brought to you for free and open access by Asia Marketing Journal. It has been accepted for inclusion in Asia Marketing Journal by an authorized editor of Asia Marketing Journal. 


\title{
Fantastic Collaboration of Financial Services and Telecommunication: a Frontier Case of Integrated Marketing Communication of "Club SK Card"
}

\author{
Seon Min Lee** \\ Seungwoo Chun*** \\ Young Hyuck Joo**** \\ Changjo Yoo*
}

In May 2012, the collaboration of Hana Bank, top financial service company, and SK Planet, top telecommunication service provider, introduced a new credit card that was filled with all-in-one benefits into the market. Leveraging strong infrastructure of two companies, each top in its own industries, the awareness and preference of 'Club SK Card" brand rapidly increased to about 25\% in less than one year. Moreover, this new card was enthroned in the most sold credit card of year 2012, accounting for a market share of $7.2 \%$ in the credit card market and more than $80 \%$ in the mobile credit card market.

To make these results possible, 'Club SK Card' marketing team developed an effective marketing communication strategy which followed the $6 \mathrm{M}$ model. The mission of the marketing communication strategy was simple and clear. It was to deliver the card's inherent strengths on consumer benefits that come from the support of subsidiary and affiliated companies of SK Planet. According to OK Cashbag data, the marketing communication team selected the appropriate target consumers and approached them directly, inducing actual purchase behavior. The target consumers received straightforward messages about 'Club SK Card' and were led to join in the new membership at their most frequently visited supermarket or franchise restaurant. The straightforward communication message embedded in an eye-catching commercial ad with a hook song accompanied with a dance was delivered via public media. The ad became so popular that many other television programs quoted or made parodies of the ad. Courtesy of the commercial ad, the brand name disseminated rapidly and widely among the public. In October 2012, an ingenious planning and persistent implementation of the communication strategy results 'Club SK Card' to be ranked top in brand awareness as well as advertising preference tests.

Key words: ‘Club SK Card’, Integrated marketing communication, 6M model

\footnotetext{
* This case is supported by SK Planet.

** Ph.D. Candidate, Korea University Business School(se0n1ee@korea.ac.kr)

*** Associate Professor of Marketing, Dongguk University(schun5@dongguk.edu), corresponding author

***** Professor of Marketing, Hansung University(mrjoo@hansung.ac.kr)

***** Professor of Marketing, Dongguk University(yoo@dongguk.ac.kr)
} 
In May 2012, Hana Financial Group Inc. and SK Telecom Co. Ltd. introduced the first generation of mobile credit card, 'Club SK Card'. It was a new type of credit card which combines financial and telecommunication services of the two brands that leads in its industry. As a major company which was responsible for the marketing communication of 'Club SK Card', SK Planet was faced with a challenge of building awareness of the newly introduced card and delivering its benefits as conveniences and economic savings that consumers could experience during their everyday lives.

Recently, the credit card market has been expanded exponentially and, accordingly, confronted with a severe competition. By the time of 'Club SK Card' introduction, the credit card market was already well established-Shinhan Card celebrated the largest market share, Hyundai Card was well known for its unique image through aggressive marketing communication practices, and $\mathrm{BC}$ Card had a history of a traditionally strong brand image. As a late entrant in this red ocean market, it was indisputable that 'Club SK Card' needed to take an assertive approach to penetrate into the consumers' minds and emphasize its strong economic and convenient benefits. In order to make this possible, the marketing communication team's task was to establish and implement a strong and effective marketing communication strategy.

The purpose of a marketing communication strategy for this new brand was simple and clear: to build a brand image that represents both Hana bank and SK, then plant it into the consumers' mind. The big advantage of 'Club SK Card' is that it provides two major benefits. First, it is an all-in-one card which is very convenient: consumers do not need to carry multiple cards in their wallets to obtain discounts, mileages, points or other economic benefits provided by different credit card companies because 'Club SK Card' allows consumers to obtain discounts all-around. Exclusive discounts are given to members in a wide range of interests-communication, gas, as well as dineout expenses. Second, it provides great service in a mobile card platform. Due to recent technological advancements, the mobile credit card service market has expanded dramatically. Mobile cards, a credit card on a cell phone platform, are expected to evolve into a type of smart phone-based digital wallet which is estimated to be a $\$ 5,250$ billion dollar market worldwide in 2020 (Person 2013).

In order to overcome its disadvantage of being a late-mover in this very competitive market, 'Club SK Card' needed to analyze the market thoroughly and select target consumers strategically. It was evident that a decent guideline for an effective marketing communication strategy planning was mandatory to take advantage of its core capabilities. Making the best use of the $6 \mathrm{M}$ model, 'Club SK Card' became 1st in the market in less than 10 months of implementing its marketing plans. It ob- 
tained more than 80\% market share in the mobile card market as well as a $7.2 \%$ share in the total credit card market in its second quarter of introduction.

\section{Introduction of 'Club SK Card': Integrated Marketing Communication Campaign}

To develop an efficient and effective marketing communication strategy, 'Club SK Card' established its integrated marketing communication strategy based on the 6M model (Donald 2002). The $6 \mathrm{M}$ model is designed to help the major decision making process throughout the marketing communication strategy-what is the objective of the communication campaign, who are the target customers of the product, what kind of communication message should be carried out to target consumers, which types of communication media vehicle to use, how much budget should be planned for an effective communication campaign, and which types of measurement would be appropriate to determine the results of the execution of the integrated marketing communication strategy accurately.

\subsection{Mission - What is your objective of communication?}

'Club SK Card' marketing communication team had a clear and prominent objective which is to imprint the value of the card on the minds of its target consumers. Its clear advantage as a credit card was the strong economic benefits. Consumers who are 'Club SK Card' members were able to receive a considerable amount of discount at numerous SK partner companies, each a leading company in major industries, including mobile telecommunication services, major supermarket chains, franchisers including family restaurants chains, bakeries, etc.

The important task for 'Club SK Card' marketing communication team was to find out an effective way to deliver the benefits of the product. Credit cards were not only a very convenient means for payments, but also an economic tool for consumers to save money by getting discounts or earn mileage points that can later be used for other expenses. However, each credit card company offered different types and rates of discounts on different domains of expenses. This became a hassle for consumers since they had to carry multiple cards to receive all the benefits they desired. For example, credit card A offers a 10\% discount at Outback Steakhouse but no discounts on women's apparel, while credit card B gives a 15\% discounts on women's apparel but not on dining. It is true that every consumer has a deep interest in saving money while shopping with credit cards. However, the established credit card brands provided financial benefits only in their specialized domains. Moreover, consumers could 
not compare the different types and rates of discounts easily at a glance. The feeling of difficulty not only came from the hard-to-compare beneficial attributes of major credit cards, but also from seeking a fit between the benefits provided by the card and consumer's individual needs. To tackle these problems, "Club SK Card' decided to provide a wide range of integrated benefits to card members through the affiliation of SK Group; SK telecommunication services, SK gasoline stations, major supermarket chains like Home Plus or E-Mart, most educational institutions, public transportations and traffic information services such as T Map, major coffee shop and dining restaurant franchise chains such as T.G.I Friday's or Bennigan's, and entertainment companies including CGV, one of the largest movie theater or multiplex chains in Korea, and Melon, the nation's leading online music-streaming service provider.

\subsection{Market - To whom is your communication addressed?}

Since the major benefit of 'Club SK Card' is based on its economic value, the target market would be individuals who are sensitive to financial benefits, such as discounts. This means that almost everyone in this country could be a potential 'Club SK Card' customer. Everyone is interested in saving money, especially in the current recession period. Therefore, the problem was not who, but how to reach the target market.

In order to approach the appropriate and available target markets, 'Club SK Card' marketing communication team leveraged the advantage of information infrastructure of SK Planet's many subsidiaries and affiliated companies. By the aid of SK Marketing \& Company's consumer information analysis system, 'Club SK Card' obtained information about individual customers who were currently subscribed to partner companies' services. SK Planet leads a family of partner companies from which it was able to obtain information of individual consumers; OK Cashbag, T Store, T Map, $11^{\text {th }}$ St., Melon, and many franchise systems such as CGV, C\&U, Home Plus, Paris Baguette, T.G.I. Fridays, etc. OK Cashbag, $11^{\text {th }}$ St. and T Map services are a part of SK Planet's integrated commerce division. OK Cashbag provides the integrated customer loyalty program in which a number of companies were registered. The system had a database of 36 million customers who have been subscribing its memberships. 11st St. provides online open market services. Also, T Map provides a various services based on its global positioning (GPS) technology, including online traffic reports, public transformation schedule and additional information about path finding or navigation services, etc. T Store is a digital content and payment platform provider and performs a matchmaking role among three parties-consumers, digital content publishers, and service providers. The integrated com- 
merce division also contains other affiliated companies of SK group including Melon, an online music streaming service provider, and many other franchise marketing channels.

Based on the results of consumer behavior data analysis provided by OK Cashbag, 'Club SK Card' chose two major target markets: members of major supermarket chains and members of major franchise restaurants. It deliberately selected the target consumers who satisfied three criteria: individuals with 1) a monthly earning of 300 million won or above, 2) substantially higher spending with credit cards in the past 3 months, and 3) a certain level of frequencies in the target store visits for shopping. Through the customer information database analysis, the 'Club SK Card' marketing communications team was able to identify the most frequently visited supermarket chains and dining restaurants by target consumers, and the most visited branches for each. As a result of exhaustive analysis, E-mart and Bennigan's were selected as the customer contact points. In-store events were held at a number of branches chosen carefully based on the average daily number of visits by target consumers. In-store promotion events induced consumers to sign up for applications. The events promoted exclusive discounts consumers could obtain at their visited channel along with the use of 'Club SK Card'. This method made 'Club SK Card' effectively and efficiently get accessed target market and recruited new credit card members. Without wasting resources, 'Club SK Card' was able to inform their target consumers directly about its instantaneous and convenient-to-use financial benefits.

\subsection{Message - What specific points must be communicated?}

The mission for 'Club SK Card' marketing communication campaign was to deliver the strength of their credit card which provides a wide range of financial benefits that cannot be duplicated by other credit card companies. To effectively fulfill this mission, 'Club SK Card' marketing communication team took two considerations into account when developing a compelling creative concept. The first consideration was that the communication message should be developed in the perspective of consumers. The message execution style should be deliberately designed to lead the consumers to perceive the financial strengths of the product concretely. In that way, consumers will perceive the benefit of 'Club SK Card' intuitively - they do not need to be bothered by the hassle of finding the appropriate credit card to get discounted and/or missing the possible chance of getting benefits due to leaving their credit card at home. The second consideration was that the creative team must find a distinctive and memorable execution style that could differentiate their communication message with the messages of their competitor's. 
Consumers have already been bombarded with too many communication messages of established credit card brands and their benefits. Simply adding one more message about the benefits of the new card would not be effective at all. Therefore, the communication message of 'Club SK Card' should avoid simply listing the explanations about its benefits. Rather, it needed to emphasize and imprint an image about an absolute and incomparable strength on its financial and economic benefits in target consumers' minds.

Above all, the marketing communication creative team elaborated a keyword for "Club SK Card' communication campaign considering these two factors in mind. The keyword should satisfy the requirement of building four types of associations that can imply the brand. The first association was about the product. The keyword needed to emphasize the merits of monetary discounts the product provides. There were various domains at which consumers could obtain discounts including gasoline stations, telecommunication fees, and supermarket chains, just to name a few. The second association was about individual benefits. The keyword needed to bring the image of joy, satisfaction and surprise that consumers could feel due to the experience of strong economic benefits carried by the card use. The third association was about the organization. The origin of consumer benefits comes from the powerful network of affiliates and subsidiaries. This accentuated the strength of the product itself which is outstanding in history, combining financial benefits from Hana Bank and convenient benefits from SK Group. The last association was about the symbolic function. The keyword needed to build a symbolic image of all benefits. It should pull in all of the other associations together and lead them to construct a symbolic image of the one and only available credit card that one can enjoy all desired benefits.

The role of the communication keyword was to embed these meanings into consumers' minds in an intuitive way. Therefore, it was critical to develop a precise and accurate but a powerful keyword rather than a long and tedious explanation about the benefits. The keyword should lead consumers to sense all the benefits in a forthright manner. After a long time of elaboration, the communication creative team brought up the strong and intact keyword of "Fantastic". "Fantastic" was selected because it emphasized the strong and amazing benefits customers could get from the card, and it represented the consumers' exclamation about the product usage experience.

After the campaign keyword of "fantastic" was chosen, the marketing communication creative team designed an execution style for the communication message in detail. It adopted a musical style that showed the endorser singing about the product. They used audio-visual elements of entertainment such as a dance and/ or a sing-a-song because they determined it 
would be an effective tool, especially considering its marketing communication campaign objective, to emphasize and embed the core benefits of the product, strong financial benefits, in consumers' minds intuitively. Generally, advertisements with advertising appeal elements such as music and dance is a useful marketing method that gives joy and fun to consumers. In that way, consumers easily become familiar with the product. The positive feeling toward the advertisement is then transferred to the product and/or a brand (MacKenzie, Lutz and Belch 1986; Shimp 1981). As a result, consumers are more likely to have a more positive attitude toward the product based on their emotion and then the positive attitude would be likely to lead consumers to purchase it. It is not only about a positive emotion for the ad transferred to the product evaluation. Additionally, consumers who enjoyed the ad could voluntarily spread positive responses about the ad (and naturally about the product) through word of mouth.

According to literature, the attitudes toward the product are established through two kinds of routes-central and peripheral routes (e.g., Petty and Cacioppo 1986). Traditionally, a rational approach based on central information about the product has been known to be effective for high-involved utilitarian products whereas the emotional approach based on peripheral information to be more effective for low-involved hedonic products (Petty and Cacioppo 1984;
Chaudhuri and Buck 1995). However, it was an innovative and challenging trial for the marketing communication creative team, to utilize this type of marketing communication style in establishing the consumer attitude via emotional routes for a credit card which is usually classified as a highly involved utilitarian product.

The final task remained for the communication creative team was how to give a concrete shape to the execution of "Fantastic". The team decided to actualize "Fantastic" in three ways: the dance, the song/jingle, and the characteristics of the endorser. First, the dance with a motion of bending knees while spinning lower arms near the waistline implied a concept of a decreasing price and consequently represented fantastic feeling of consumers. Second, the lyrics of the commercial jingle song repeatedly exposed the keyword, "fantastic". Finally, it was critical to choose an endorser who could perform the dance and the commercial jingle song well as well as who could be able to represent target customers. After a number of meetings, interviews, and rejections, the communication creative team chose Yoo Jun-Sang, an actor as well as a musical star, as the endorser. As a musical actor, he was fully capable of performing the fantastic jingle song and dance. Also, he had a favorable image of an ideal son (and son-in-law) which was carried over from a role he had starred in a popular TV drama recently broadcasted. 
〈Figure 1〉 Communication Message-Fantastic Dance Performed by Yoo Jun-Sang
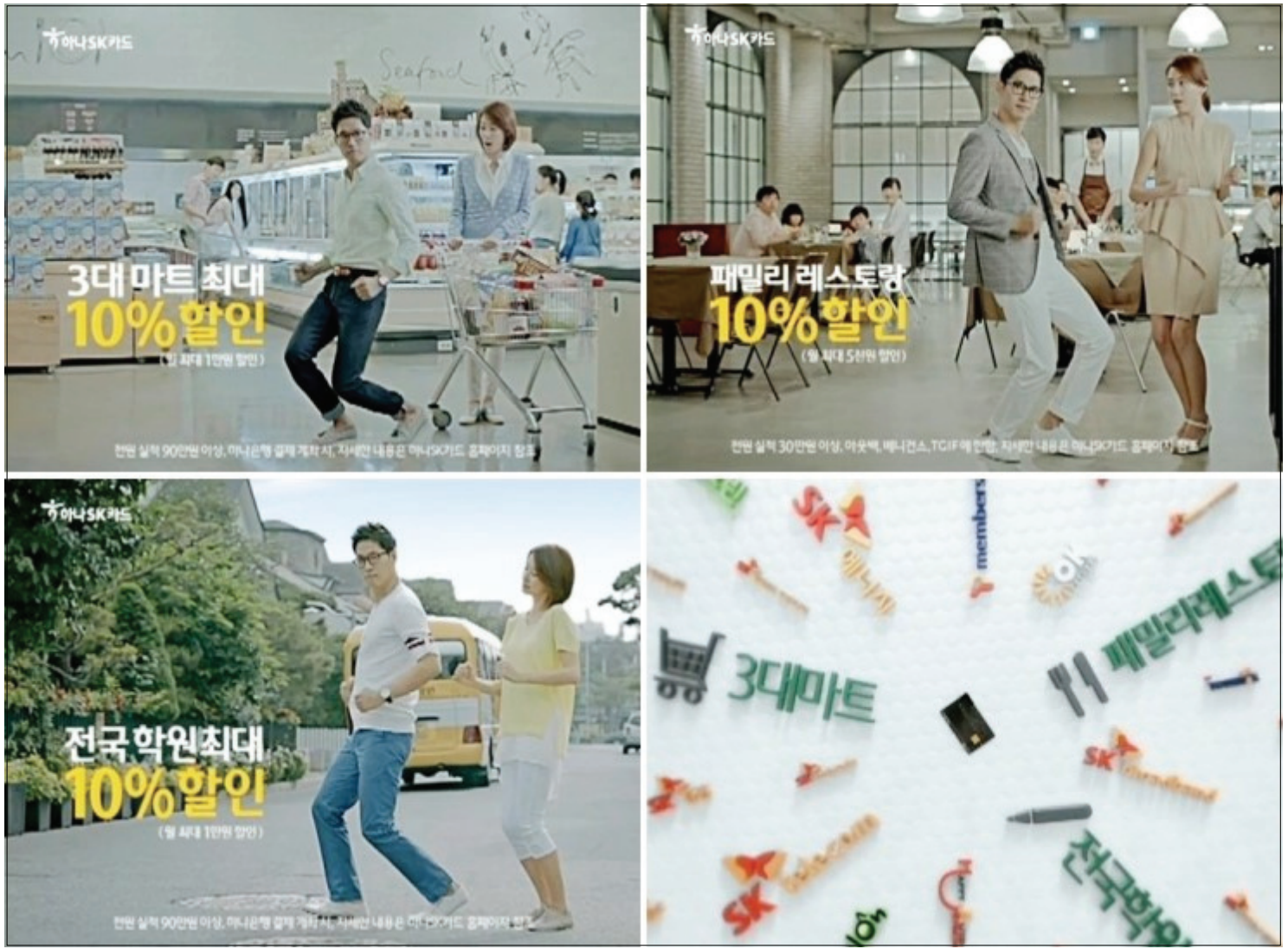

\subsection{Media - What communication vehicles were used to get the message across?}

The objective of media coverage plan was simple: maximize the media impact. In order to determine the media impact, the planning for media coverage was engaged with two purposes; broad reach of the communication message through major public broadcasting services and frequent exposure of communication message to the right target consumers at the right contact points.

First, the marketing communication media team should choose media that will engage consumers rather than simply reach them. The media team made the best use of its affiliates and subsidiaries channels to boom up the fantastic jingle and dance. The mix of media was selected from a wide array of new media such as Internet, home shopping channels, and outdoor sports games of the SK affiliates and subsidiaries. Second, the content of communication message was directly delivered to target 
〈Figure 2〉 Communication Message - the Fantastic Song Was Registered at Melon, an Online Music Distributor Which is an Affiliated Company of SK

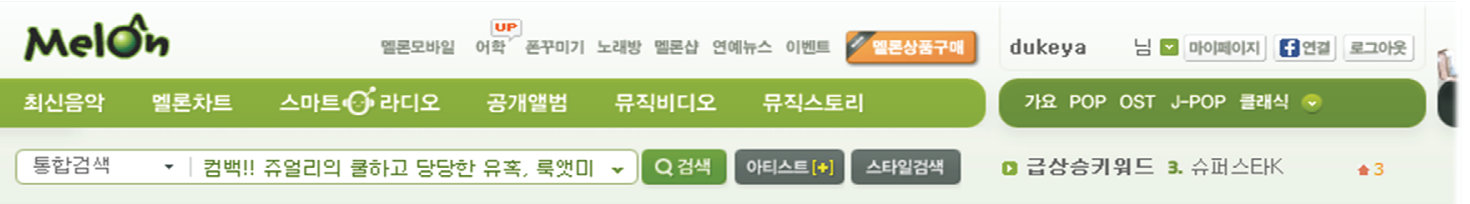

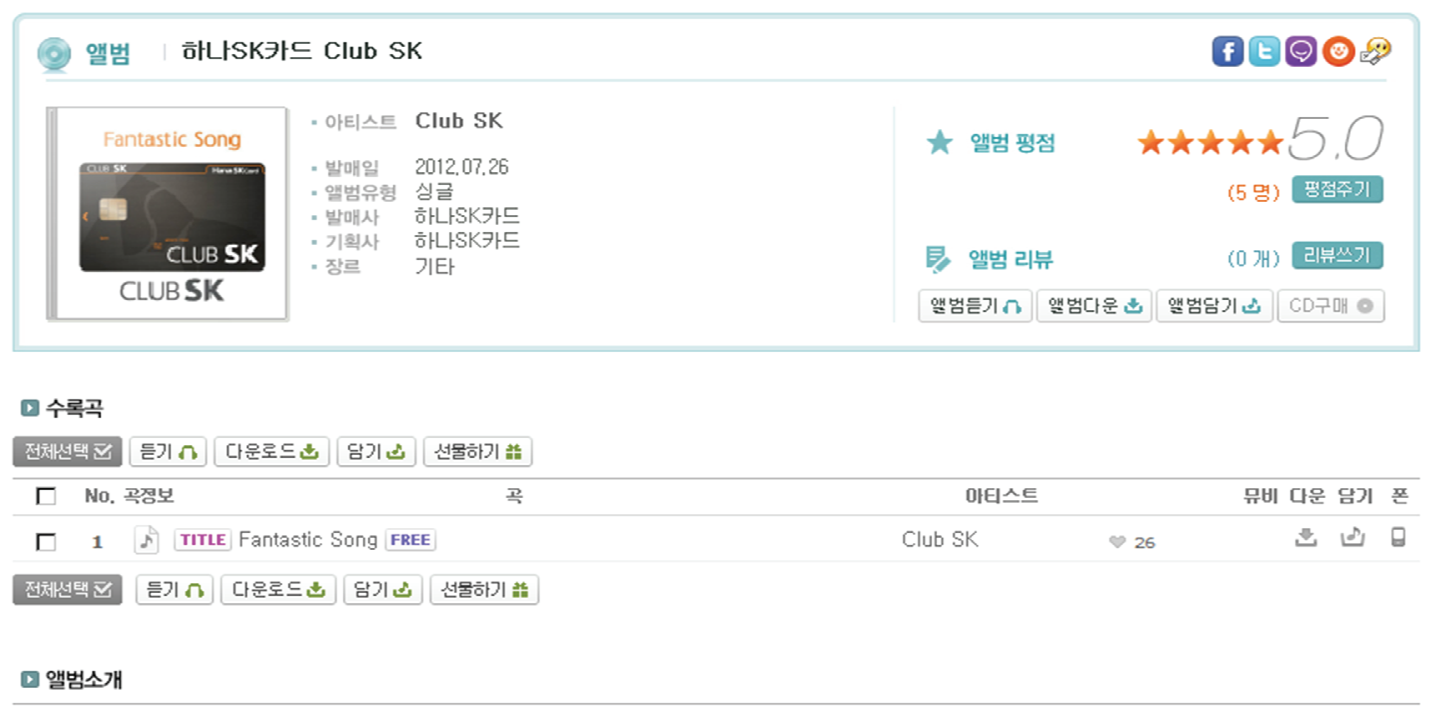

CLUB SK [하나SK카드 Club SK]

유준상의 하나SK카드 CLUB SK 광고 BGM, 하나SK카드 CLUB SK의 혜택의 졸거움을 연상할 수 있도록 하고자, 신나는 리듬에 반복되는 '판타 스틱' 이 라는 가사를 활용하며 제작 하였다.

consumers who were contacted at the major supermarkets and franchise restaurants. The direct communication toward target consumers was expected to initiate their behavior of applying for issuing the card (as known as pull strategy, Kotler and Armstrong 2012). The event marketing was an effective tool to ex- plicitly emphasize huge benefits on gasoline and telecommunication fee discounts consumers could obtain by conveniently using the all-in-one card services. Based on consumer density information obtained from OK Cashbag database, metropolitan areas in Seoul such as Yeouido, Jong-ro, Gwanghwamun, and Gangnam areas were chosen 
for venues at which to hold event driven marketing which facilitated consumers to apply for a new credit card with a special offer or free gift for sign-ups.

In addition to event driven marketing, TV advertisements as well as the recommendation from close acquaintances were known to be an efficient method to elicit consumers' actions. In order to satisfy this second phased implementation, media coverage plan was developed into three steps, illustrated in the conceptual diagram (Figure 3). The purpose of the first step was to $\max ^{-}$ imize brand awareness and recognition. In order to achieve this purpose, the communication media team made the best use of SK Planet's business infrastructure for spreading "Fantastic Dance" in wide coverage. The "fantastic dance" was performed and broadcasted at various me- dia such as Lotte home shopping, baseball games of SK Wyverns, and Melon. Those media were owned by either affiliated companies or subsidiaries of SK. The purpose of the $\mathrm{sec}^{-}$ ond step was to induce target consumers to become a member. The candidates were selected through OK Cashbag database analysis. The candidate consumers were given mobile coupons which can be redeemed at their most frequently visited stores. Consumers were recommended to sign up or to use the credit card at major consumer contact points including EMarts and Bennigan's restaurants. The purpose of the third step was to diffuse the "Fantastic Dance" through earned media. Fortunately, numerous parodies were produced voluntarily by the public and broadcasted in various TV show programs including famous weekend comedy

〈Figure 3〉 Conceptual Diagram of Implementation Strategy

\begin{tabular}{|c|c|c|}
\hline Exposure & Membership & Diffusion \\
\hline $\begin{array}{l}\text { - Purpose: } \\
\text { - Expose the communication } \\
\text { message to consumers for } \\
\text { recognition of the brand }\end{array}$ & $\begin{array}{l}\text { - Purpose: } \\
\text { - Approach to potential } \\
\text { consumers to issue the card }\end{array}$ & $\begin{array}{l}\text { - Purpose: } \\
\text { - Build up the flow by } \\
\text { diffusing the message } \\
\text { through earned/owned media }\end{array}$ \\
\hline $\begin{array}{l}\text { - Activity: } \\
\text { - Fantastic song/dance } \\
\text { - Practically utilize the } \\
\text { channels of affiliated } \\
\text { companies }\end{array}$ & $\begin{array}{l}\text { - Activity: } \\
\text { - Encourage to join } \\
\text { membership by introducing } \\
\text { initial/repeat purchase } \\
\text { - Encourage consumers to } \\
\text { actively participate in } \\
\text { promotions by broad } \\
\text { exposure to media }\end{array}$ & $\begin{array}{l}\text { - Activity: } \\
\text { - Voluntary diffusion among } \\
\text { consumers and media } \\
\text { - Announcements about } \\
\text { upcoming events using SNS }\end{array}$ \\
\hline
\end{tabular}


〈Figure 4〉 Exposure of the Communication Message

a. A capture image of "Fantastic Dance" performed by a shopping host at Lotte Home Shopping Channel, one of affiliated companies.

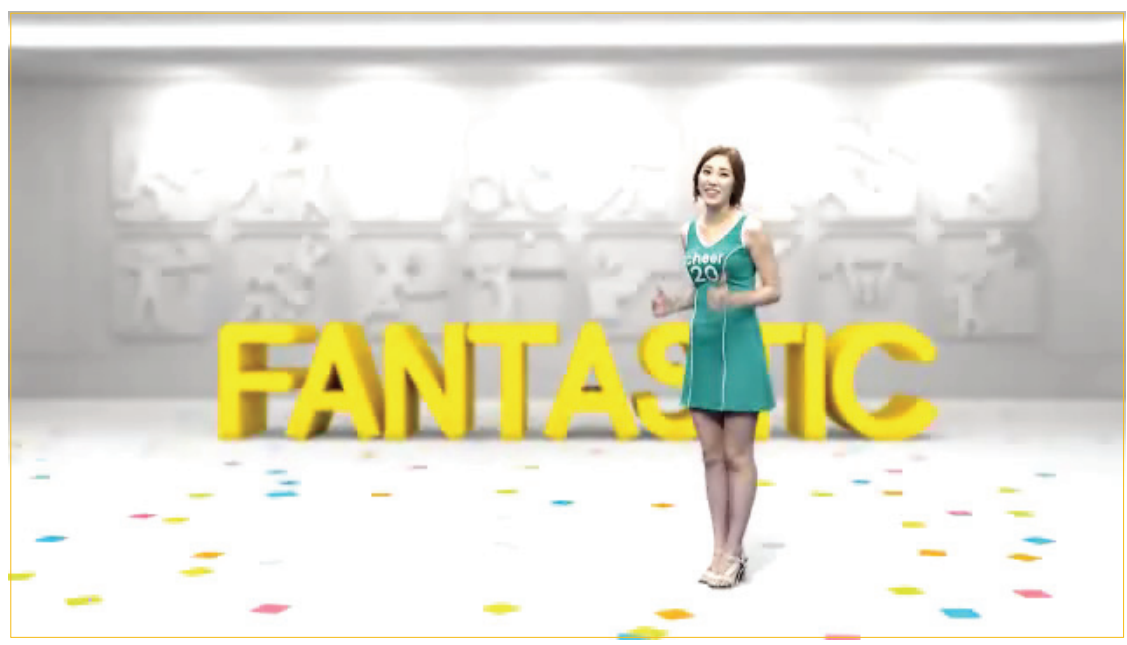

b. "Fantastic Dance" performance as a cheerleading event at baseball games of SK Wyverns, one of subsidiary companies.

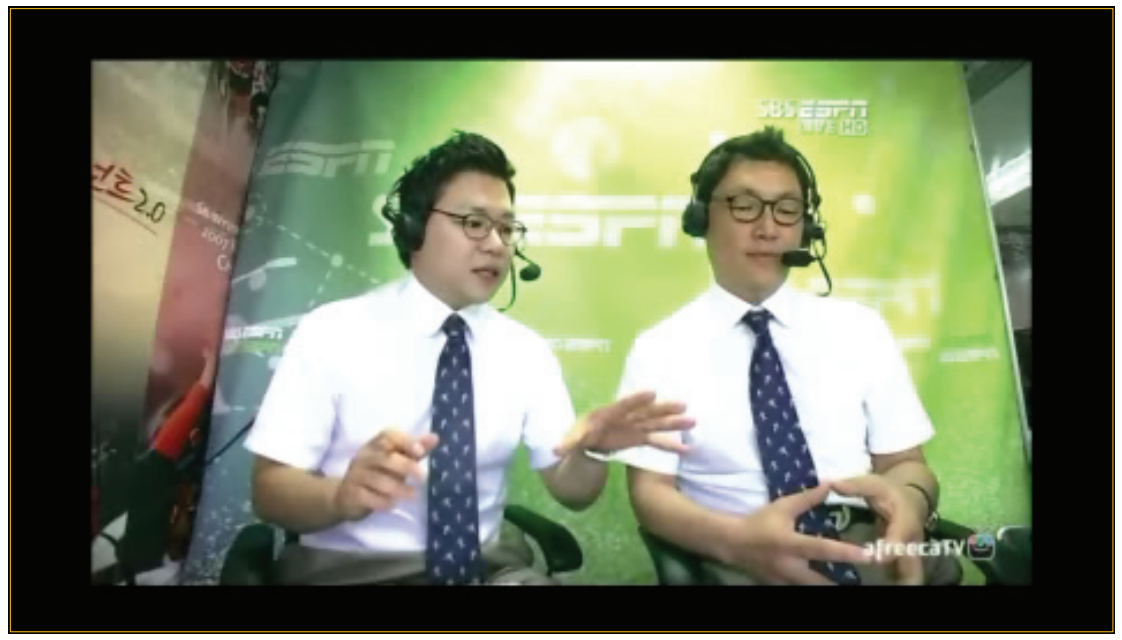

shows - 'Gag Concert' and 'Infinite Challenge' which were a representative program of KBS and $\mathrm{MBC}$ respectively. Also, Yoo Jun-Sang, the endorser of the brand, who attended the Busan International Film Festival as a guest and performed the "Fantastic Dance" as a response to the publics' request at the premiere red carpet event. 
〈Figure 5〉 The Membership of the Card

a. Mobile Database

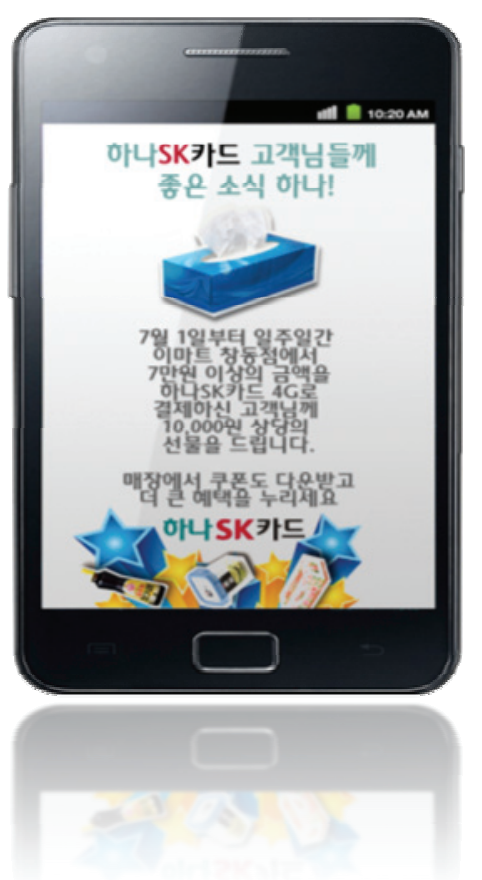

Candidates were selected among E-Mart consumers through OK Cashbag Database

- Monthly income of 3,000,000 won and above

- The usage records in recent 3 months

- Frequency of visits and average amounts of spending per visit at E-Mart

Select the appropriate branches for events marketing to be held considering an anticipated number of new memberships and scales of sales at each branch.

Selected numbers of target consumers were given mobile coupons inducing to join and use Club SK Card at the specific branch store.

\section{b. Events Marketing}

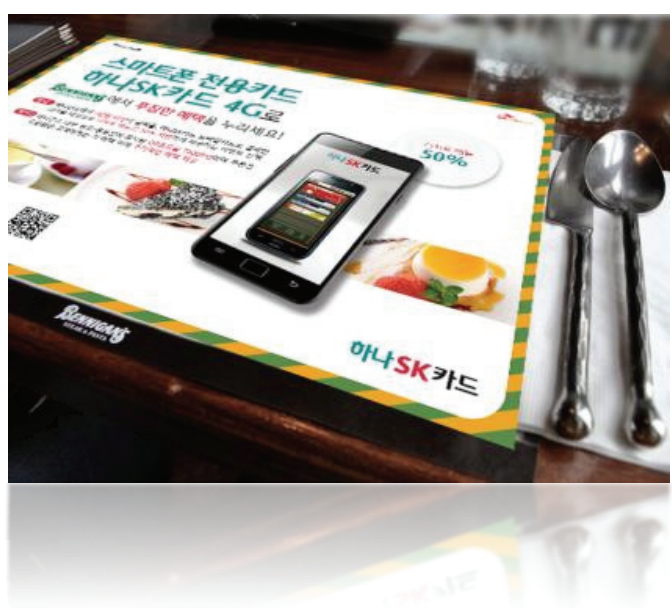

The most frequently visited restaurant brands and branch locations were analyzed through OK Cashbag Database

- Average number of dine-outs per month

- Major area of dining places and most frequently visited brands

- Average expenses per dine-out

Bennigan's, one of SK alliances, were selected as customer contact points

- The highest volume of sales comes from unit of family customers

- Family restaurants as a major type of restaurants for family outing places

Ads about Club SK Card is printed on paper table mats.

Ad informs customers of Hana SK Card being issued at Bennigan's, one of alliance companies of OK Cashbag 
〈Figure 5〉 The Membership of the Card (continue)

c. Indoor/Outdoor Advertisements at E-Mart

$\langle$ Ad besides the Escalator〉

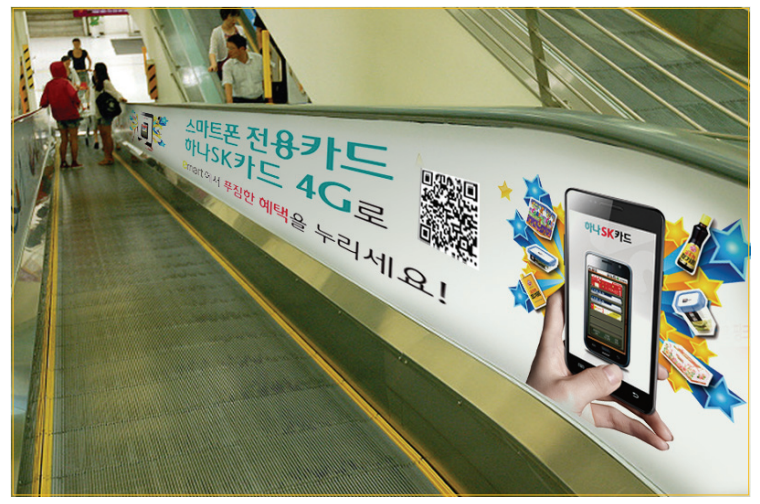

$\langle$ Ad on Carts〉

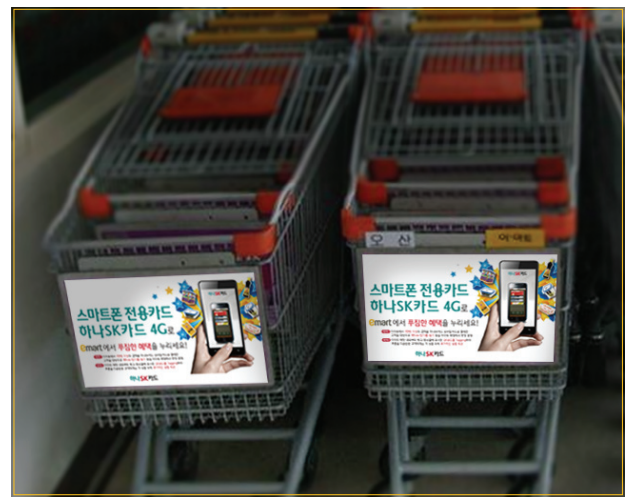

〈Figure 6〉 Diffusion of the Communication Message: Parody about Fantastic Dance Was Performed at Various Shows - Public Relations

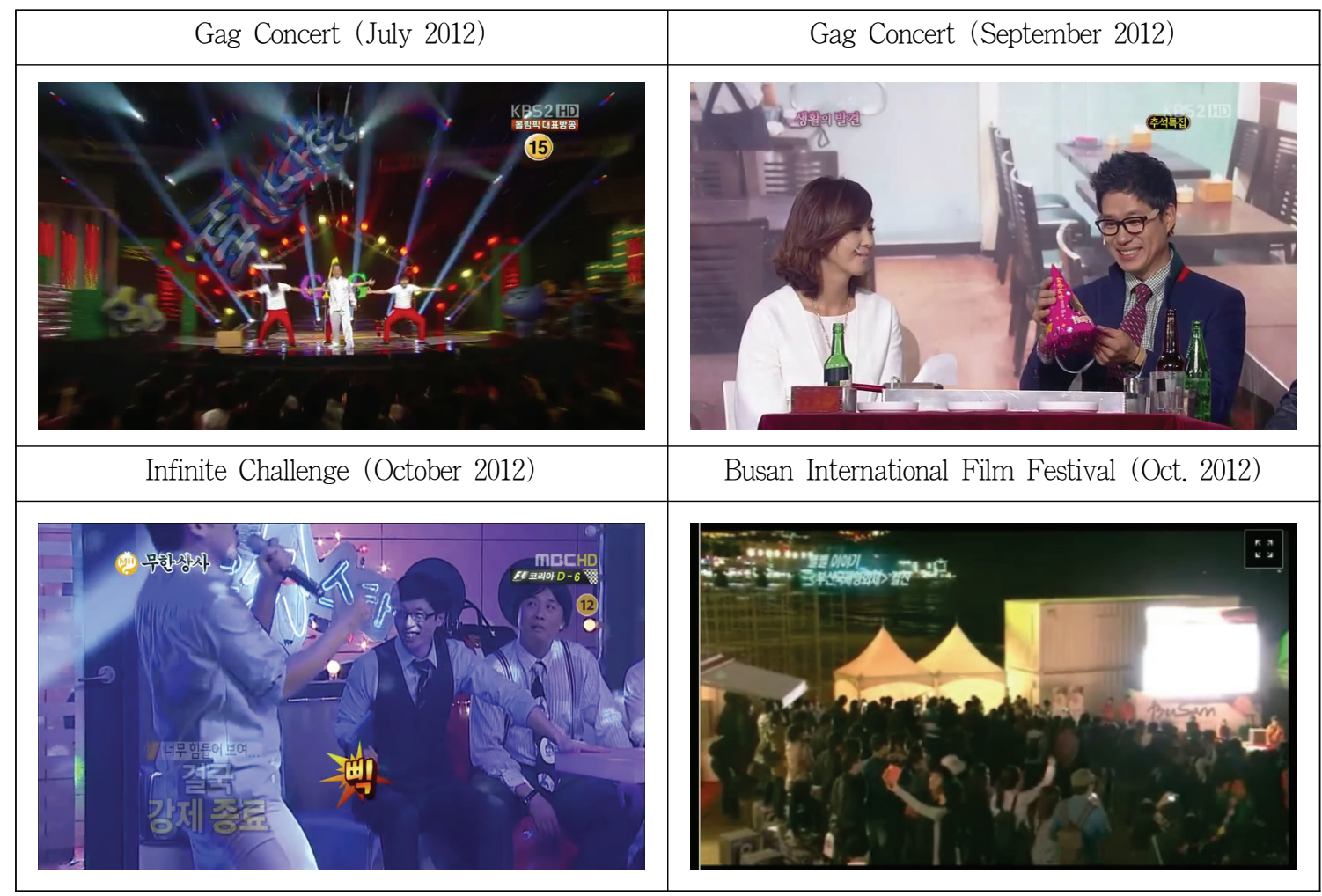




\subsection{Measurement - How was the impact of your communication?}

Every effort of the communication campaign was clearly focused on informing customers about the core benefits of 'Club SK Card' in an intuitive and vibrant style. The results of the communication campaign can be measured based on three criteria: 1) brand awareness, 2) brand preference, and 3) sales performance (total number of new cards issued).

\subsubsection{Brand Awareness was Incomparable to its Competitors}

As a result of communication campaigns, the consumer awareness of 'Club SK Card' was incomparable compared to its competitors' major brands. 'Club SK Card' held a 24.78\% awareness followed by 'Lotte VEEX Card' then 'KB Kookmin Haedam Card' on aided brand name recall test (refer Table 1). In a survey of 787 participants about credit card brand awareness, 'Hyundai M Card' marked 29.99\% followed by 'Club SK Card' with 24.78\%. Ever since its launch in May 2003, 'Hyundai M Card' has invested annual communication budgets of over 30 billion won. Comparing budgets and durations of the campaigns between two brands, the recognition rates among consumers indicated that consumers' brand awareness of 'Club SK Card' almost caught up that of 'Hyundai M Card'. This is a surprising result considering that 'Club SK Card' was introduced in May, 2012, 9 years after 'Hyundai M Card' launch.

To measure consumers' brand awareness (recall and recognition), Tillian Panel Survey was conducted in August 2012. In the age range of $20-49$, a total of 300 people who live in metropolitan and suburbs of Seoul and Gyeonggi-do region were participated in the survey. They were given credit card brand names without

\section{〈Table 1〉 Aided Awareness of Credit Card Brand Names}

Q. Select all of credit card names which you've already known or ever heard of.

\begin{tabular}{|c|c|c|}
\hline Brand Names & Number of “yes” Answers & Recognition Rates \\
\hline CLUB SK & 195 & $24.78 \%$ \\
\hline VEEX & 131 & $16.65 \%$ \\
\hline HAEDAM CARD & 100 & $12.71 \%$ \\
\hline DIRECT & 73 & $9.28 \%$ \\
\hline 5(FIVE) & 33 & $4.19 \%$ \\
\hline LESSON CARD Platinum \# & 19 & $2.41 \%$ \\
\hline Total & 787 & $100 \%$ \\
\hline
\end{tabular}

* The recognition rates of each credit card brands were calculated by using Hyundai M Card (29.99\%) as a comparison index. Ever since launched in May 2003, Hyundai M Card continuously spend more than 30 billion won annually. Every brand in the table were relatively young which were launched after 2012 except VEEX card which was introduced in 2011. 
〈Table 2〉 Initial Recall of Advertising Elements

[단위 : \%]

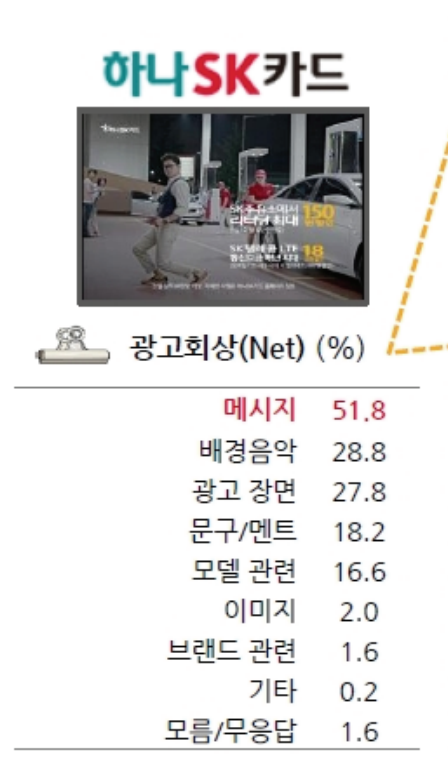

\begin{tabular}{l|c}
\hline \multicolumn{1}{|c|}{ 메시지 } & $(\%)$ \\
\hline 주유비 할인 & 13.8 \\
\hline 통신비 할인 & 11.2 \\
\hline 할인 혜택 & 1.4 \\
\hline SK 계열사의 할인 혜택이 크다 & 2.8 \\
\hline 스토리 & 1.0 \\
\hline 메시지 & 0.4 \\
\hline 내려간다 & 0.4 \\
\hline 전월 실적 60 만원 이상 & 0.2 \\
\hline 광고의 연속성 & 0.2 \\
\hline 신용카드 &
\end{tabular}

\begin{tabular}{l|l}
\multicolumn{1}{c|}{ 문구/멘트 } & $(\%)$ \\
\hline $\begin{array}{l}\text { 카드 하나로 SK의 모든 혜택을 } \\
\text { 누리다 }\end{array}$ & 7.2 \\
\hline 통신비 할인도 되네 & 6.4 \\
\hline 카드 하나로 & 2.0 \\
\hline SK의 모든 혜택을 누리다 & 1.8 \\
\hline 고객이 즐거워 한다면 이 정도 & 0.8 \\
\hline 쯤이야
\end{tabular}

\begin{tabular}{l|c}
\hline \multicolumn{1}{|c|}{ 모델 관련 } & $(\%)$ \\
\hline 유준상 & 10.4 \\
\hline 모델 관련 & 6.2 \\
\hline
\end{tabular}

\begin{tabular}{|c|c|}
\hline 배경음악 & $(\%)$ \\
\hline 배경음악 & $15.6 \cdot$ \\
\hline 판타스틱 & $13.2^{\circ} 0^{\circ}$ \\
\hline
\end{tabular}

\begin{tabular}{|l|c}
\hline \multicolumn{1}{|c|}{ 이미지 } & $(\%)$ \\
\hline 이미지 & 1.6 \\
\hline 검은색 & 0.2 \\
\hline 신뢰 & 0.2 \\
\hline
\end{tabular}

\begin{tabular}{l|c}
\hline \multicolumn{1}{|c|}{ 광고 장면 } & $(\%)$ \\
\hline 유준상이 춤추는 장면 & $13.2 \%$ \\
\hline 춤 & 10.2. \\
\hline 휘발유 가격이 내려가는 모습 & 2.6 \\
\hline 주유소 & 1.6 \\
\hline 유준상이 할인혜택에 놀라는 모습 & 0.2 \\
\hline
\end{tabular}

\begin{tabular}{l|c}
\multicolumn{1}{|c|}{ 브랜드 관련 } & $(\%)$ \\
\hline SK & 0.8 \\
\hline CLUB SK 카드 & 0.6 \\
\hline 카드회사 & 0.2 \\
\hline
\end{tabular}

\begin{tabular}{|l|c|}
\hline \multicolumn{1}{|c|}{ 기타 } & $(\%)$ \\
\hline 소비자를 기만 & 0.2 \\
\hline
\end{tabular}

\begin{tabular}{|l|c|}
\hline 모름/무응답 & $(\%)$ \\
\hline 모름/무응답 & 1.6 \\
\hline
\end{tabular}

\begin{tabular}{|l|c|}
\hline \multicolumn{2}{|c|}{ Advertisement Recall (Net) (\%) } \\
\hline Message & 51.8 \\
\hline Background Music & 28.8 \\
\hline Advertisement Scenes & 27.8 \\
\hline Campaign Key Word & 18.2 \\
\hline Endorser & 16.6 \\
\hline Images & 2.0 \\
\hline Brand-related & 1.6 \\
\hline Others & 0.2 \\
\hline Don't Know/ No Response & 1.6 \\
\hline
\end{tabular}

showing the parent company names in order to prevent any bias the participants might fall into from associating credit card brands with brand power of parent companies. Results of the Tillian Panel Survey indicated that 'Club SK Card' scored high on both brand aware- ness and recognition test. Consumers recalled many of the elements shown in the advertisement which included not only the major messages about target benefits, but also fantastic dance, background music, jingle, the endorser, and the campaign keyword. Table 2 describes 
the details about survey results of consumers' most recalled elements in advertisement.

\subsubsection{Brand Preference}

The 'Club SK Card' ranked the highest score on advertising content comprehension and preference tests among all other credit card brands. Many survey participants answered "the ad is easy to understand" and "I like the ad" in the ad evaluations.

Figure 7 represents the position of "Club SK Card' out of major competitor ads on the positioning map with ad comprehension rates on the vertical axis and ad preference rates on the horizontal axis. Besides, Table 3 provided information about accumulated advertising expenses for each credit card brand.

\subsubsection{Sales Performance}

As a result, 'Club SK Card' ranked No. 1 in new credit cards issue performance among its competitors. It made the highest sales records of 750,000 new issues in 2012 followed by Korea Exchange Bank (KEB) 2X Card of 650,000 issues. It was announced as 2012 product of the year award winner in financial category (refer Figure 8).

〈Figure 7〉 Credit Cards Positioning Map based on Advertising Preference and Comprehension

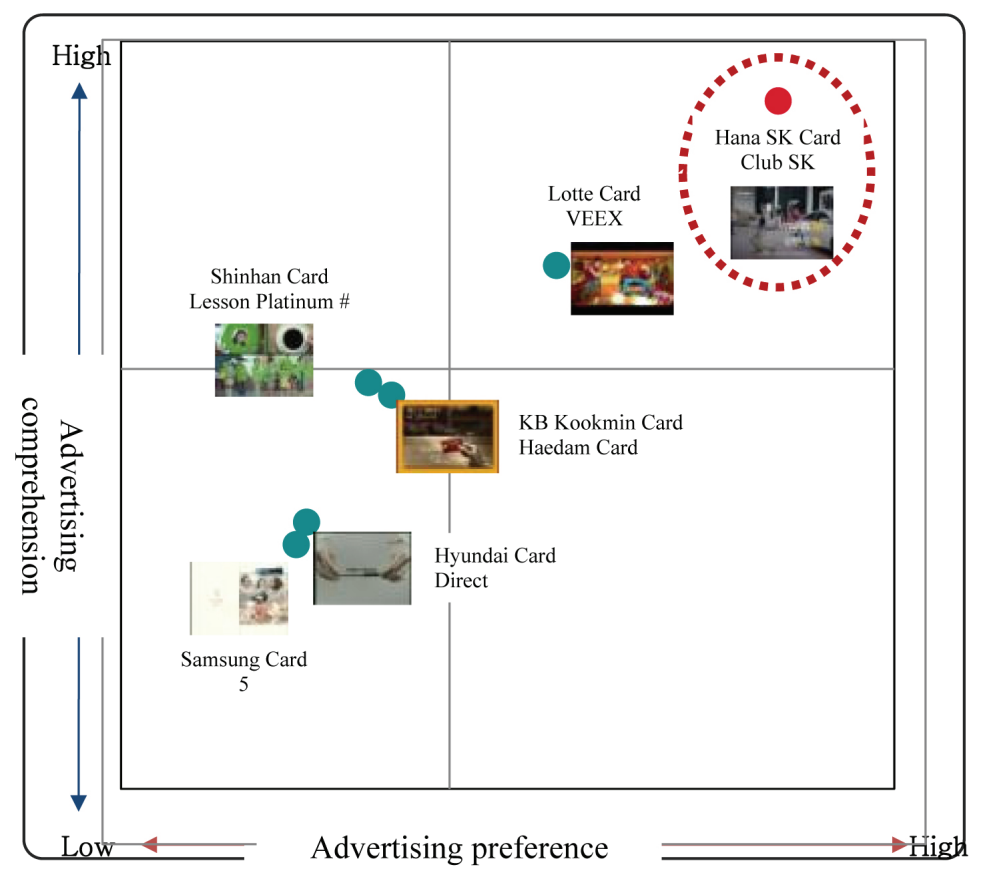

* Measurements of advertising effectiveness for each credit card brands (Tillion survey reports in July 2012) 
〈Table 3〉 Accumulated Advertising Expenses (Public + Cable TV) for Each Credit

Card Brands (Source: KADD/ May-July 2012)

\begin{tabular}{|c|c|}
\hline Credit Card Brands & Expenses \\
\hline 'Club SK Card' & 9.6 billion \\
\hline Lotte Card VEEX & 2.4 billion \\
\hline KB Kookmin Card Haedam Card & 1.8 billion \\
\hline Shinhan Card Lesson Platinum \# & 2.5 billion \\
\hline Hyundai Card Direct & 2.6 billion \\
\hline Samsung Card 5 & 2.1 billion \\
\hline
\end{tabular}

〈Figure 8> Sales Performance of Hana SK Card in 2012

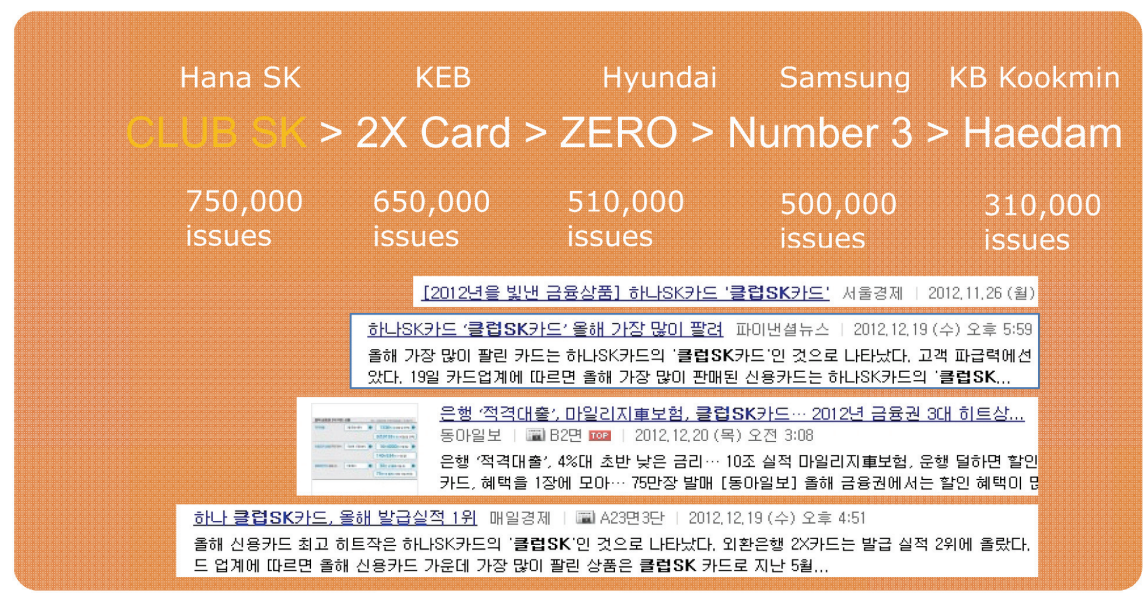

\section{Conclusion}

The output of the collaborative project between Hana Bank and SK Planet, 'Club SK Card', was successfully delivered to consumers by carefully following $6 \mathrm{M}$ model which guided the brand's integrated marketing communication strategy. First, the simple and clear objective of the marketing communication was driven. Second, the up-to-date consumer in- formation provided by OK Cashbag helped to select accessible target market. Third, the intuitive communication message using dance and jingle were developed to persuade consumers directly about the benefits of product. Fourth, the effective use of traditional and new media mix helped to reach the maximum impact of advertising. Fifth, the deliberative implementation strategy enabled the marketing communication campaign to attain its goal without wasting of communication budget. Lastly, the effective- 
ness of the marketing communication strategy for building brand awareness and recognition were measured afterwards.

Two major elements of SK Planet infrastructure played a critical role for the successful launch of 'Club SK Card' throughout the whole process. The vast scope of database about customer information provided by OK Cashbag made the accessible target consumers selected. And a sufficient infrastructure of SK Group made it possible to access the target consumers.

The advertising message with the key word "Fantastic" was carefully designed to deliver the benefits in an intuitive way so that consumers could easily perceive and understand the possible benefits they will receive by using the 'Club SK Card'. The fantastic song and dance helped serving the idea and, fortunately, consumers perceived the advertising fun and interesting. This resulted in an unexpected effect. Consumers spread the fantastic song and dance on non-conventional media voluntarily and without any fees. This led 'Club SK Card' to focus most of communication efforts on directly approaching target customers through distribution channels like E-mart or Bennigan's. They paid careful attention to avoid their communication efforts meaninglessly wasted to unspecified individuals. While minimizing the communication budget spend for traditional public media, they rather made active use of the new media or earned media to disperse their communication message broadly.
As a result of smart strategy planning and effective implementation, 'Club SK Card' became the most newly issued credit card in a short period of time. 'Club SK Card' was introduced in May 2012 and scored first in brand awareness, preference, and sales according to a survey conducted in October 2012. The success of 'Club SK Card' was the result of its marketing frontier spirit and its determined execution of carefully planned marketing communication strategy.

\section{References}

Carvens, David W. (2002), "Strategic Marketing Management Cases," Boston, Mass. McGraw Hill, New York, p.324-325.

Chaudhuri, Arjun and Ross Buck (1995), "Media Differences in Rational and Emotional $\mathrm{Re}^{-}$ sponses to Advertising," Journal of Broadcasting and Electronic Media, 39(1), 109125.

Kotler, Philip and Gary Armstrong (2012), Principles of Marketing, Edinburgh, England: Prentice Hall.

MacKenzie, Scott. B., Richard J.. Lutz and George Belch (1986), "The Role of Attitude toward the $\mathrm{Ad}$ as a Mediator of $\mathrm{Ad}^{-}$ vertising Effectiveness: A Test of Competing Explanations," Journal of Marketing Research, 23(2), 130-143. 
Person, Lita (2013), "Mobile Wallet Market (Applications, Mode of Payment, Stakeholders and Geography) - Global Share, Size, Industry Analysis, Trends, Opportunities, Growth and Forecast, 2012 - 2020," Allied Market Research, November 26.

Petty, Richard E. and John T. Cacioppo (1984), "The Effects of Involvement on Responses to Argument Quantity and Quality: Central and Peripheral Routes to Persuasion," Journal of Personality and Social Psychology, 46 (1) 69-81.

Petty, Richard E. and john T. Cacioppo (1986), "The Elaboration Likelihood Model of Persuasion," in Communication and Persuasion: Central and Peripheral Routes to Attitude Change, eds., NY: Springer, 1-24.

Shimp, Terence (1981), "Attitude toward the Ad as a Mediator of Consumer Brand Choice," Journal of Advertising, 10(2), 9-15. 